\title{
Клиничен случай на тромбоза на синус сигмоидеус и синус кавернозус и церебрит от отогенен произход
}

\author{
Асенов А., Василева Д., Делчев И., Митев Б. \\ Отделение по УНГ-болести към МБАЛ - Пловдив
}

\begin{abstract}
Резюме: Описан е рядък случай на тромбоза на синус сигмоидеус и церебрит с отогенен произход при полиморбиден мъж на 68 години. Разгледани са диагностичните проблеми, терапевтичният подход и резултатите от лечението.
\end{abstract}

\begin{abstract}
A rare case of otogenic sigmoid sinus thrombosis in a male 68 years old polymorbid patient is described. The diagnostic problems, therapeutic approach and the results of the treatment are being presented.
\end{abstract}

\section{Въведение}

Тромбозата на сигмоидния синус е смятана за често усложнение на инфекциите на средното ухо в началото на миналото столетие със смъртност, достигаща $100 \%$ при нетретирани случаи. В ерата след широкото навлизане на антибиотиците в практиката честотата на това усложнение намалява значително, а смъртността е сведена до около 10\%. Общата смъртност при тромбоза на сигмоидния синус достига 30\%, като най-честа причина е септичната кардиомиопатия, острият респираторен дистрес синдром и гърчовете. Резистентността на патогенните микроорганизми към антибиотици в наши дни е считана за основна причина за отново нарастващата честота на тромбозата на сигмоидния синус като усложнение на острите и хронични отити.

\section{Представяне}

Мъж на 68 г. постьпва в УНГ-отделение с оплаквания от болки в лявото ухо от около 2 месеца. Провел амбулаторно лечение с перорални антибиотици, без клиничен резултат.

\section{Introduction}

At the beginning of the last century sigmoid sinus thrombosis was a common complication of middle ear infections, with lethality close to $100 \%$ in untreated patients. In the age of antibiotics the prevalence of this complication significantly diminished and lethality dropped to $10 \%$. Overall lethality by sigmoid sinus thrombosis reaches $30 \%$ with septic cardiomyopathy, acute respiratory distress syndrome and seizures being the most common cause of death. Antimicrobial resistance is considered main reason for raising numbers of sigmoid sinus thrombosis as a complication of acute and chronic otitis.

\section{Presentation}

68 year old man was admitted at our department with complaints of pain in the left ear for the last 2 months, treated with peroral antibiotics without any result. 


\section{Обективно}

От прегледа се установи умерено оточна и палпаторно болезнена горна част на паротидната жлеза вляво и оток на долната стена на ляв външен слухов проход.

Отоскопия - Помътнена тъпанчева мембрана, без категорични данни за остро възпаление на средното ухо.

Аудиометрия - комбиниран тип хипакузис двустранно.

Параклиника - WBC: 11,1; RBC: 4,0; HGb: 127; CУЕ: 113

Микробиологично изследване на ушен секрет - изолира ce Klebsiella pneumoniae.

Придружаващи заболявания - ИБС, КМП, стенокардия, АХ гр. II, СН II-ІІІФК, преживян долен МИ, ЗД 2 тип, преживян тромбофлебит на долни крайници, обезитас, диабетна ретино- и полиневропатия.

\section{Диагноза}

Постави се работна диагноза otitis externa circumscripta sinistra; диференциална диагноза - тумор на паротидната жлеза.

\section{Терапевтичен подход}

Осъществи се инцизия на кожата на долната стена на външния слухов проход, при която не се попадна на гнойна колекция. Взе се материал за хистологично изследване, който показа кръвен съсирек с елементи от церумен. Осъществи се тьнкоиглена биопсия на паротидната жлеза - без резултат. Проведе се медикаментозно лечение: Medocef 2x1 g; Clindamycin 2x600 mg; Amikacin 2x500 mg; Ciprinol 2x300 mg; Perfalgan $2 x 1$ g. Оплакванията на пациента персистираха.

Осъществи се КАТ на задна черепна ямка и мастоидите - КТ данни за МСБ, церебрална и церебеларна атрофия, без данни за огнищен възпалителен процес. Двустранно промени в темпорални кости, както при хроничен възпалителен процес - заличени и уплътнени клетъчни системи - по-изразено вляво.

\section{Examination}

moderate swelling of the upper portion of left parotid gland with pain on palpation and swelling of inferior wall of external auditory meatus. Tympanic membrane is cloudy, but no clear otoscopic signs of middle ear infection.

"

Audiometry: mixed type hearing loss.

Blood tests: WBC 11,1 RBC 4,0 HGB 127 ESR 113

Microbiology examination of ear swab: Klebsiella pneumoniae

Comorbidities: IHD, Cardiomyopathy, Angina pectoris, Arterial hypertension, Myocardial infarction type 2, Thrombophlebitis of lower extremities, Diabetic neuropathy and retinopathy

\section{Working diagnosis}

Otitis externa circumscripta

Differential diagnosis: Tu glandulae parotis

\section{Therapeutic Approach}

Incision of the suspected furuncle of the inferior wall of external auditory meatus was unsuccessful, no collection was evacuated biopsy showed cerumen and coagulated blood.

Fine needle aspiration biopsy of parotid gland revealed no pathology.

Medicamental treatment applied: Medocef $2 \times 1$ g; Clindamycin 2x600 mg; Amikacin 2x500 mg; Ciprinol 2x300 mg; Perfalgan 2x1 g.

Patients complaints persisted.

CT scan of mastoids and posterior fossa was performed, showing signs of Cerebrovascular disease and cerebellar atrophy with no signs of focal inflammatory process of the brain. Bilateral alteration of temporal bones with signs of chronic inflammation. 

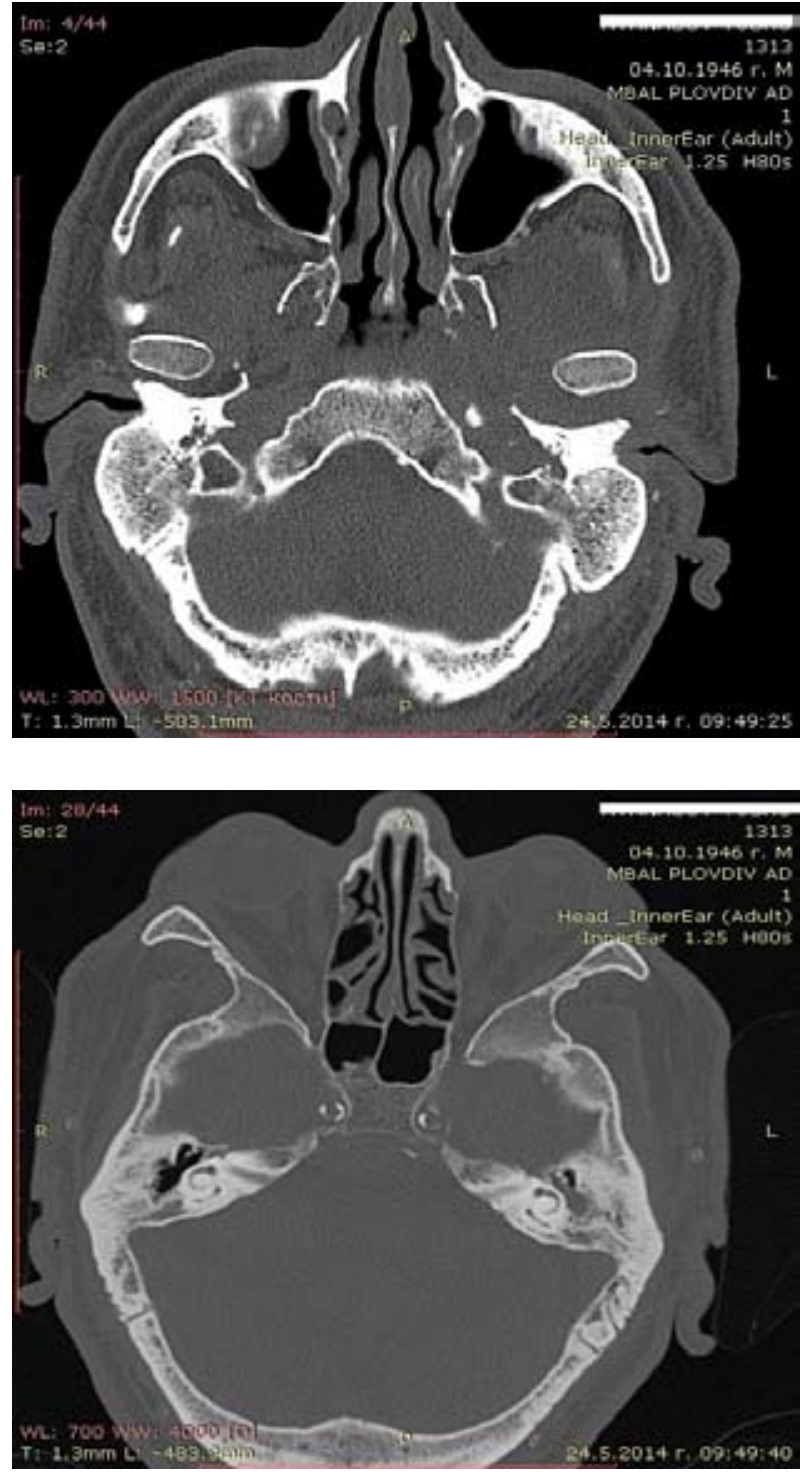

Пациентьт се насочи за оперативно лечение в планов порядък, с препоръки за контрол на АН и кр. захар. След 8 дни пациентьт се рехоспитализира и се осъществи радикална трепанация вляво - с ретроаурикуларен достъп по модификацията на Пайво се откри планум мастоидеум със задна стена на ВСП. С бормашина се свали кортикалисът на мастоидната кост, като се откри сину-дуралният ъгъл, синус сигмоидеус и дурата. Откри се епитимпанумът. Инкудостапедиалната става се освободи от обхващащите я гранулации. Свали се задната стена до нивото на канала на нервус фациалис, без да се отваря. Кожата на задната стена се сряза и се адаптира към кухината заедно с ламбо от мускулус окципиталис. По време на операцията се откри синус сигмоидеус в срединната му част. Осъществи се пробна пункция. Наложи се геласпонова тампонада. Оперативното поле се затвори посредством
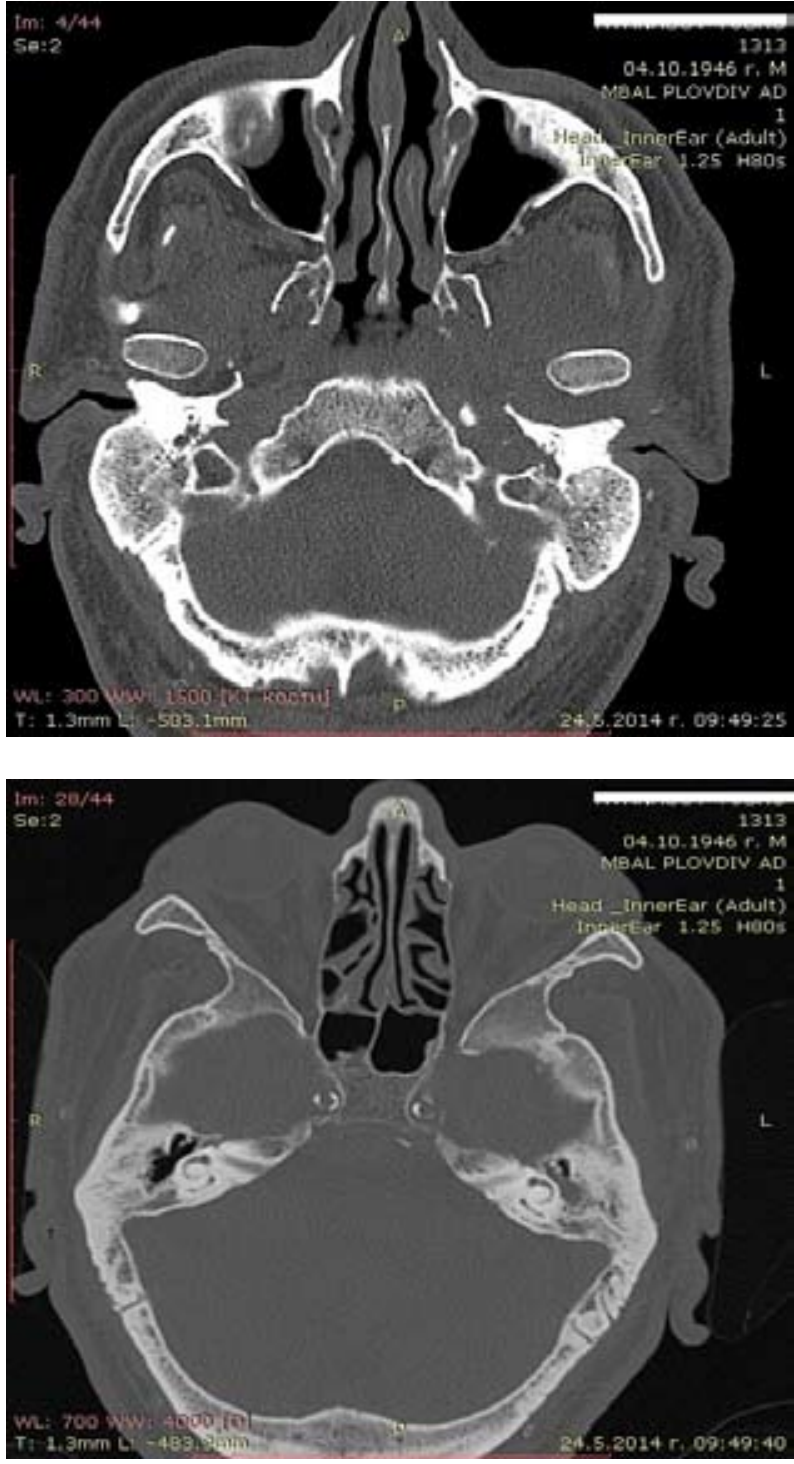

The patient was scheduled for surgical treatment. 8 days later the patient was rehospitalsed and radical mastoidectomy of the left temporal bone was performed. After the sinus sigmoideus, the dura and the sinodural angle were revealed, sigmoid sinus was exposed in its middle part and exploratory puncture was performed, followed by gelfoam tamponade. Granulation tissues in the epitympanum, blocking the incudostapedial joint, were removed and the bony canal of the facial nerve was identified. Histological examination of tissues from middle ear showed chronic nonspecific inflamation. Postoperative care period passed without complications. 5 days after surgery the patient developed peripheral paresis of the facial nerve on the left side. 
послойно обшиване. Направи се превръзка. Изпрати се материал за хистологично изследване, който показа хроничен неспецифичен отит. Следоперативният период премина спокойно, беше извьршван редовен тоалет и смяна на превръзките. Оперативното поле беше спокойно. На петия ден след операцията се установи пареза на нервус фациалис от периферен тип.

Извърши се КАТ на главен мозък и задна черепна ямка - състояние след левостранна мастоидектомия. Няма КТ данни за пресни огнищни лезии от исхемичен и хеморагичен характер. ХМСБ, мозъчна атрофия от сенилен тип.

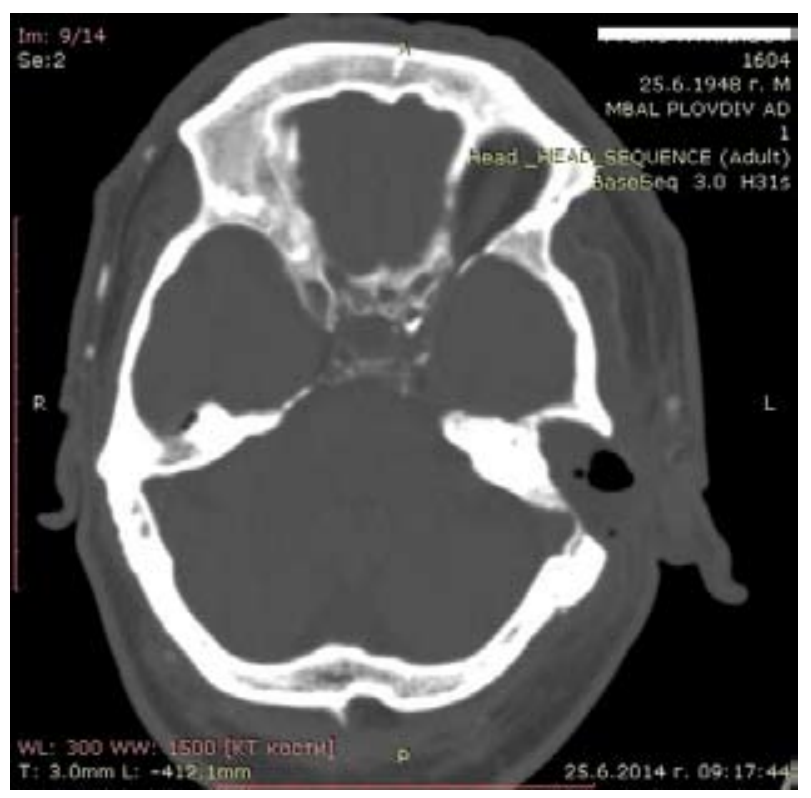

Пациентьт съобщаваше за периоди на главоболие и стягане във врата, гадене и повръщане. Общото състояние на пациента се влоши, стана сомнолентен. Имаше периоди, в които даваше неадекватни отговори на зададените му въпроси. Появи се десностранна хемипареза. Осъществи се консултация с кардиолог, невролог и ендокринолог, които коригираха антихипертензивната и антихипергликемичната терапия. Параклиничните резултати показаха данни за активна инфекция - WBC - 13,2; CRP- 76,8; CУЕ - 150.
Another CT scan was performed showing the usual outcome of radical mastoidectomy without compliucations and no signs of focal ischaemic or haemorrhagic lesions of the brain tissue.

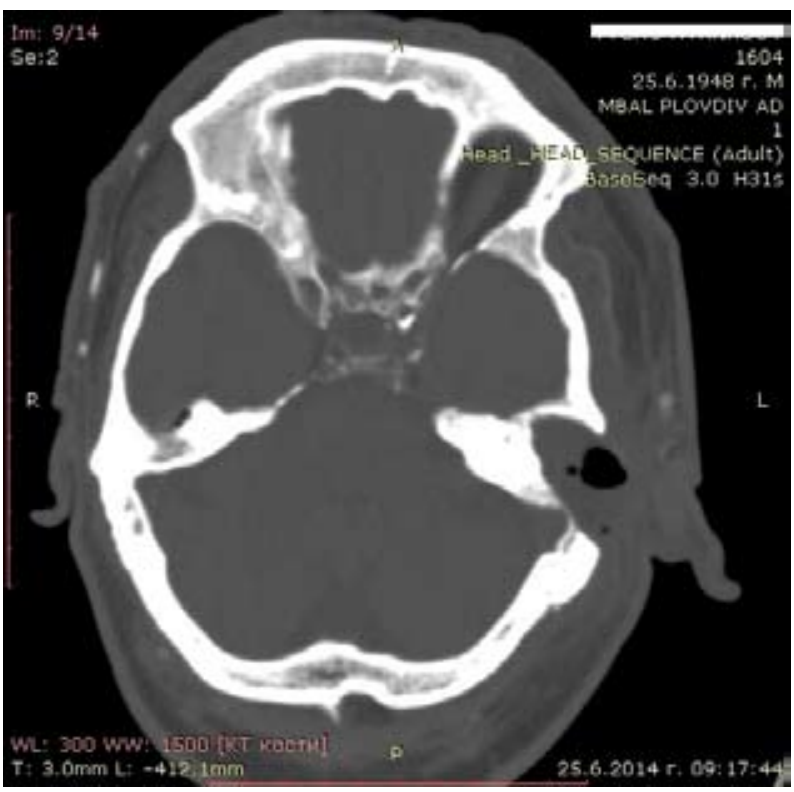

The patient reported headache, stiffness in the neck, nausea. His general condition worsened and he became somnolent with periods of confusion. Signs of right sided hemiparesis appeared. Consultations with cardiologist, neurologist and endocrinologist were made in order to adjust his antihypertensive and antihyperglicemic therapy. Blood tests were suggesting the persistence of an active infection - WBC - 13,2; CRP- 76,8; ESR - 150MRI of the brain with induction of with contrast matter was performed and cerebritis was diagnosed, while also showing thrombosis of the left internal carotid artery, possibly a pre existing one. 


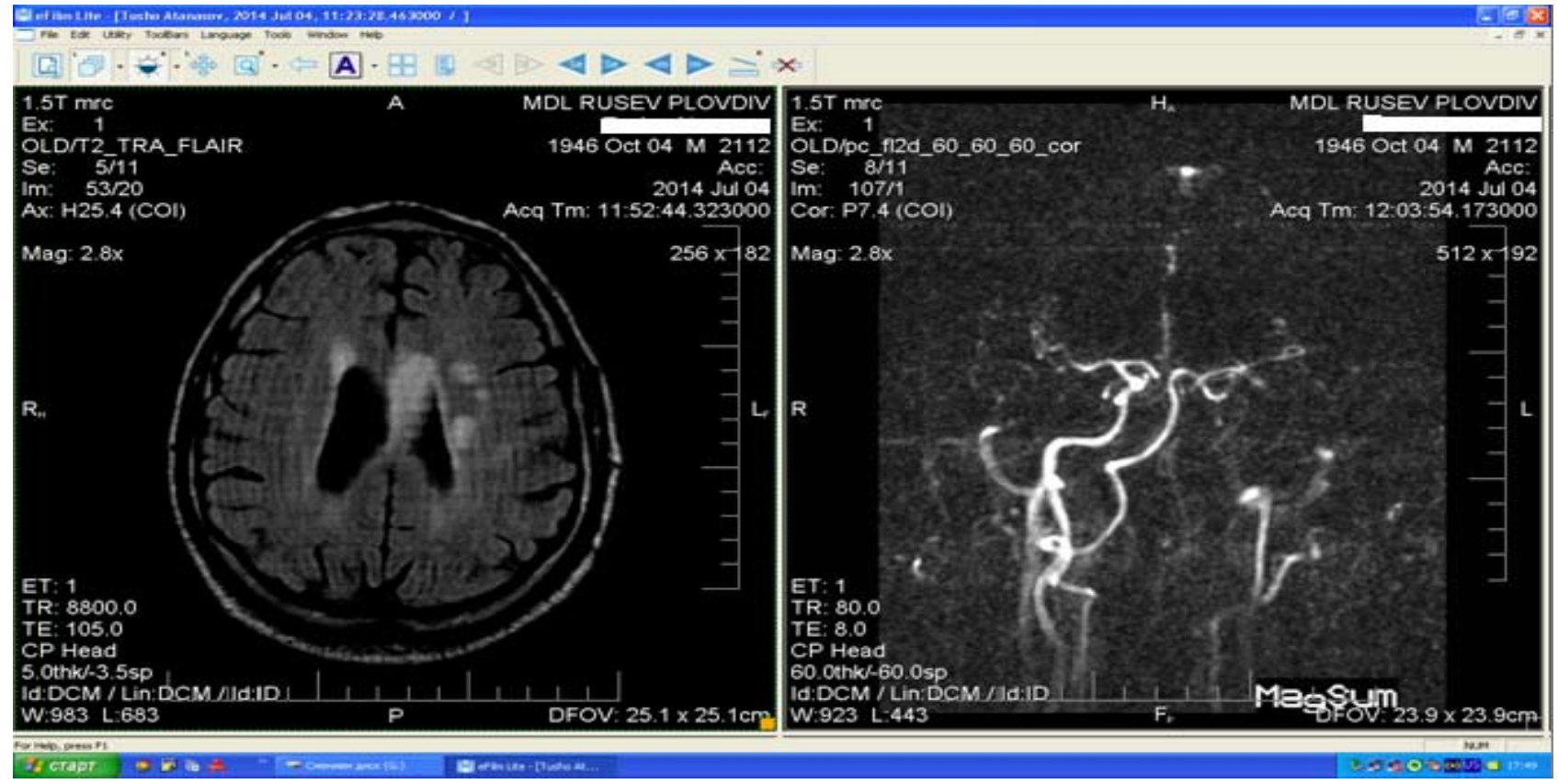

Осъществи се ЯМР на главен мозък - церебрит, тромбоза на а. каротис интерна синистра с неясна давност, данни за тробмоза на синус сигмоидеус и синус кавернозус вляво.

Проведе се консултация с офталмолог - диабетна ретинопатия. Проведе се консултация с инфекционист. Осъществи се лумбална пункция без данни за бактериална или вирусна инфекция в ликвора. Направи се EXO кардиография без данни за ендокардит.

Проведе се следното медикаментозно лечение: Amikacin 2x500 mg за 22 дни; Meronem 2x1 g за 10 дни; Maxipime 2x1 g за 10 дни; Exomax 200 мг/24 ч за 11 дни; Clexan 2x0,4 за 11 дни, Mannitol 10\% 2x 250 мг за 10 дни, Vancomycin $3 \times 1$ г за 9 дни; Biseptol 2x2 ампула за 11 дни, Melbec по 1 ампула дневно; Profenid по 1 ампула дневно; Milgamma N по 1 ампула дневно; Nootropil по 2 г дневно; Degan при нужда; ВСР; антихипертензивни и антихипергликемични медикаменти.

Параклиничните показатели започнаха да влизат в референтни стойности. Пациентът не съобщава за нови субективни оплаквания. При изписването персистират лезията на нервус фациалис от периферен тип вляво и десностранната хемипареза.
Unconvincing MRI evidence of of left cavernous and sigmoid sinus thrombosis were also presented. Another consultation with ophtalmologist confirmed the diagnosis diabetic retinopathy. Infectious disease specialist performed lumbar puncture, but the results of CSF examination did not confirm the suspicion of bacterial or viral neuroinfection. Echocardiography was performed to exclude endocarditis.

Following medicamentous treatment was applied: Amikacin 2x500mg for 22 days; Meronem 2x1g for 10 days; Maxipime 2x1g for 10 days; Exomax $200 \mathrm{Mr} / 24 \mathrm{~h}$ for 11 days; Clexan $2 \mathrm{x} 0,4$ for 11 days, Mannitol 10\% 2x 250мг for 10 days, Vancomycin $3 \times 1 \Gamma$ for 9 days; Biseptol $2 \times 2$ aмп for 11 days, Melbec 1амп daily; Profenid 1 амп per day; MilgammaN 1амп per day; Nootropil 2г per day; Degan when needed Results of paraclinical tests slowly returned to normal. The patient did not report any new complaints. The patient was discharged with persisting left sided paresis of the facial nerve and right sided hemiparesis. 


\section{Заключение}

Познаването и ранната диагностика на тромбозата на кавернозния и сигмоидния синус е от изключителна важност, тъй като в предантибиотичната ера тези усложнения на ушните инфекции са били, почти без изключение, фатални. Образната диагностика е ключова за точна диагноза и планиране на оперативния подход. Дори в наши дни резултатите при лечение на тромбоза на синус сигмоидеус не винаги са задоволителни, въпреки агресивната терапия.

\section{Литература}

1. Lateral Sinus Thrombosis in Otology: a Review B. Viswanatha, Khaja Naseeruddin Mediterr J Hematol Infect Dis. 2010; 2(3): e2010027.

2. Thrombophlebitis of venous sinuses in otitis media Kuczkowski J. Otoloryngol. Pol. 2007; 61(5): 769-73. doi: 10.1016/S00306657(07)70523-1.

3. Lateral sinus thrombosis as a complication of acute mastoiditis C. Bianchini, C. Aimoni, S. Ceruti, DL Grasso, A. Martini Acta Otorhinolaryngol Ital. 2008 Feb; 28(1): 30-33.

\section{Conclusion}

Knowing the symptoms and early diagnosis of cavernous and sigmoid sinus thrombosis is crucial, because in the preantibiotic age these complications of ear infections were almost without exceptions fatal. Imaging is key for diagnosing and planning the surgical approach. Even today when treating sigmoid sinus thrombosis the results are not always satisfying, no matter how aggressive the therapy is.

\section{Bibliography}

1. Lateral Sinus Thrombosis in Otology: a Review B. Viswanatha, Khaja Naseeruddin Mediterr J Hematol Infect Dis. 2010; 2(3): e2010027.

2. Thrombophlebitis of venous sinuses in otitis media Kuczkowski J. Otoloryngol. Pol. 2007; 61(5): 769-73. doi: 10.1016/S00306657(07)70523-1.

3. Lateral sinus thrombosis as a complication of acute mastoiditis C. Bianchini, C. Aimoni, S. Ceruti, DL Grasso, A. Martini Acta Otorhinolaryngol Ital. 2008 Feb; 28(1): 30-33. 